\title{
Sistem Informasi Pengolahan Data Pendidikan Anak Usia Dini (PAUD) Terpadu Amalia Syukra Padang
}

\author{
Nency Extise Putri ${ }^{1}$, , Supriandi Azpar ${ }^{2}$ \\ ${ }^{1,2}$ STMIK INDONESIA PADANG \\ e-mail: n_cyland@yahoo.co.id
}

\begin{abstract}
ABSTRAK
Pendidikan Anak Usia Dini (PAUD) merupakan pendidikan sebelum pendidikan dasar serta sebagai salah satu bentuk penyelenggaraan pendidikan yang menitikberatkan pada dasar ke arah pertumbuhan dan perkembangan fisik motorik koordinasi dan kecerdasan yang meliputi kekuatan pikiran, kreativitas, kecerdasan emosional , kecerdasan spiritual, sosial-emosional kondisi (sikap, perilaku, dan agama) serta bahasa dan komunikasi. Prioritas Pembelajar PAUD untuk anak usia 2 sampai 6 tahun. Penelitian ini dilakukan untuk membuat sebuah program aplikasi yang dapat melakukan pengolahan data dalam Pendidikan Anak Usia Dini PAUD Terpadu Amalia Syukra Padang dan dapat memberikan solusi terhadap permasalahan yang dihadapi. Hal ini dilakukan untuk mengatasi masalah sistem pengolahan data Pendidikan Anak Usia Dini yang masih manual, yaitu pengolahan data masih menggunakan Microsoft Excel. Sistem informasi yang diusulkan yang dapat digunakan oleh beberapa pengguna secara individual sesuai dengan hak mereka sendiri. Pengolahan Data Sistem Informasi Pendidikan Anak Usia Dini (PAUD) Terpadu Amalia Syukra Padang dibuat menggunakan bahasa pemrograman VB. Net 2010 didukung oleh database MySQL. Dengan Sistem Informasi Pengolahan Data Pendidikan Anak Usia Dini (PAUD) Terpadu Amalia Syukra Padang dapat memproses data dengan waktu yang relatif singkat, sehingga menghasilkan laporan yang cepat dan akurat.
\end{abstract}

Kata Kunci: Sistem Informasi, Pendidikan

\section{PENDAHULUAN}

Sistem informasi adalah serangkaian prosedur formal dimana data dikumpulkan, diproses menjadi informasi, dan didistribusikan kepada pengguna. Penggunaan sistem informasi tidak akan lepas dari pemakaian peralatan yang dapat mengatasi kelemahan dalam sistem informasi yang mengandalkan tenaga manusia. Untuk itu perlu suatu sistem pengolahan data yang menggunakan peralatan modern sebagai penunjangnya. Salah satu contohnya yaitu komputer yang dapat menangani pengolahan data dalam jumlah yang sangat besar, kompleks serta memperkecil kesalahan yang dilakukan.
Sebuah perusahaan atau instansi hendaknya memilih suatu teknologi yang akan membantu dalam penyelesaian pekerjaan sehingga biaya yang dikeluarkan sebanding dengan pendapatan dan dapat digunakan dalam proses pengambilan keputusan. Sistem yang telah ada sebelumnya haruslah di update, karena perkembangan informasi. Oleh karena itu, perlu adanya rancangan sebuah sistem informasi yang sesuai dengan kebutuhan perusahaan atau instansi yang bersangkutan, begitu juga dengan PAUD Terpadu Amalia Syukra Padang yaitu sebuah sekolah untuk pendidikan anak-anak usia dini yang sedang berkembang, sehingga membutuhkan 
sistem pengolahan data yang komputerisasi.

Dari hasil penelitian penulis di PAUD Terpadu Amalia Syukra J1.Pelupuh No Padang, pengolahan data masih menggunakan Microsoft Excel, sehingga membutuhkan beberapa hari untuk menyelesaikan laporan pengolahan data Pendidikan Anak Usia Dini tersebut, untuk itu penulis mencoba membahas dan merancang sebuah sistem informasi yang nantinya dapat digunakan oleh PAUD Terpadu Amalia Syukra Padang.

Pada sistem saat ini, terjadinya kesulitan dalam pengolahan data siswa masuk, siswa lulus, biodata guru, kelas siswa, tabungan siswa, pembayaran uang SPP, gaji guru dan uang keluar yang terkait kepada pembuatan laporan siswa masuk, siswa lulus, biodata guru, kelas siswa, tabungan siswa, pembayaran uang SPP, gaji guru dan laporan uang keluar. Setiap terjadi keraguan data dalam sebuah laporan, pegawai harus membolak-balikan sheet dan pengoreksian dilakukan pada semua laporan pendidikan anak usia dini tersebut. Pembuatan laporan tidak efektif dan efesien serta sering terjadi ketidak samaan data antara satu laporan dengan laporan yang lainnya. Dengan adanya suatu program komputer maka permasalahan yang ada dapat diselesaikan dalam waktu yang relatif cepat, tepat, dan teliti serta tidak membutuhkan banyak waktu untuk pembuatan laporan tersebut.

Berdasarkan permasalahan itu, Penulis mencoba membuat sebuah karya ilmiah yang berjudul : "Sistem Informasi Pengolahan Data Pendidikan Anak Usia Dini (PAUD) Terpadu Amalia Syukra Padang". Dengan adanya sistem aplikasi ini dapat membantu pegawai PAUD Terpadu Amalia Syukra Padang melakukan pengolahan data pendidikan. Sistem aplikasi ini mampu mempermudah dalam pencarian data, dapat menjamin data pendidikan selalu aman dan menyajikan laporan dengan efektif dan efesien.

Pada penelitian ini penulis menggunakan Bahasa Pemrograman VB. Net 2010 dan Database MySQL, serta metode penelitian yang penulis gunakan adalah metode pengumpulan data, analisa dan Software Development Life Cycle (SDLC)

\section{LANDASAN TEORI}

Landasan teori yang digunakan pada penelitian ini adalah sebagai berikut:

\section{a. Konsep Dasar Sistem Informasi}

Menurut Tata Sutabri (2012:38)

dalam buku "Analisis Sistem Informasi", mendefinisikan "Sistem Informasi adalah suatu sistem di dalam suatu organisasi yang mempertemukan kebutuhan pengolahan transaksi harian, mendukung operasi, bersifat manejerial dan kegiatan strategi dari suatu organisasi dan menyediakan pihak luar tertentu dengan laporan-laporan yang diperlukan". Sedangkan Sistem Informasi menurut Rohmat Taufiq (2013:17) dalam buku "Sistem Informasi Manajemen", mendefenisikan "Sistem informasi adalah kumpulan dari sub-sub sistem yang saling terintegrasi dan berkolaborasi untuk menyelesaikan masalah tertentu dengan cara mengolah data dengan alat yang namanya komputer sehingga memiliki nilai tambah dan bermanfaat bagi pengguna". Berdasarkan pengertian di atas, maka sistem informasi adalah kombinasi dari teknologi informasi dan aktifitas orang yang menggunakan teknologi tersebut untuk mendukung operasi dan manajemen. 


\section{b. Sekilas tentang Pendidikan}

Pendidikan adalah merupakan bagian dari upaya untuk membantu manusia memperoleh kehidupan yang bennakna hingga diperoleh suatu kebahagiaan hidup, baik secara individu maupun kelompok. Sebagai proses, pendidikan memerlukan sebuah sistem yang terprogram dan mantap, serta tujuan yang jelas agar arah yang dituju mudah dicapai. Pendidikan adalah upaya yang disengaja. Makanya pendidikan merupakan suatu rancangan dan proses suatu kegiatan yang memiliki landasan dasar yang kokoh, dan arah yang jelas sebagai tujuan yang hendak. Jalaludin (2002:81).

Adapun Filosofi pendidikan adalah pelaksanaan pandangan Falsafah dalam bidang pendidikan. Falsafah ini mencerminkan satu segi dari segi pelaksanaan Falsafah umum dan menitikberatkan kepada pelaksanaan prinsip-prinsip dan kepercayaankepercayaan yang menjadi dasar dari Falsafah umum dan menyelesaikan masalah pendidikan secara praktis. AlSyabany (1979:30).

\section{c. Sistem Informasi Pengolahan Data Pendidikan Usia Dini (PAUD) Terpadu Amalia Syukra Padang}

Pengolahan data Pendidikan Anak Usia Dini PAUD Terpadu Amalia Syukra Padang yang dilakukan dengan menggunakan Microsoft Excel diperbaharui dengan menggunakan sistem aplikasi berbasis sistem informasi. Aplikasi pengolahan data Pendidikan Anak Usia Dini (PAUD) Terpadu Amalia Syukra Padang membutuhkan entri data siswa, guru, staf adm, data kelas siswa dan data tabungan siswa, data pembayaran uang spp, data kelulusan siswa, dan data uang keluar yang tersimpan di dalam database, sehingga sistem informasi Pendidikan Anak Usia Dini menghasilkan laporan-laporan yang efektif dan efisien.

\section{d. Bahasa Pemrograman Visual Basic Net. 2010}

Microsoft Visual Studio adalah sebuah Integrated Development Environment buatan Microsoft Coroporation. Microsoft Visual Studio dapat digunakan untuk mengembangkan aplikasi dalam native code (dalam bentuk bahasa mesin yang berjalan di atas Windows) ataupun managed code (dalam bentuk Microsoft Intermediate Language di atas .NET Framework). Selain itu, Visual Studio juga dapat digunakan untuk mengembangkan aplikasi Silverlight, aplikasi Windows Mobile (yang berjalan di atas .NET Compact Framework). Visual Basic mencakup sebuah kode editor yang didukung oleh fitur intellisense atau yang disebut dengan code refactoring. Debugger telah terintegrasi bekerja pada level source level debugger dan level debugger mesin. Toll built in mencakup form desainer untuk membangun sebuah aplikasi GUI, web desainer, class desainer dan database schema desainer.

Microsoft Visual Studio didukung bahasa pemrograman yang berbeda. Adapun bahasa pemrograman yang didukung oleh Visual Basic Studio adalah bahasa pemrograman $\mathrm{C}++$, Visual Basic, Visual C\#. Visual Studio juga dapat mendukung bahasa pemrograman lain seperti $M$, phyton 
diusulkan dapat diuraikan sebagai berikut:

1. Siswa atau wali siswa memberikan data siswa kepada Staf Administrasi (PAUD) Terpadu Amalia Syukra Padang untuk melakukan pendaftaran siswa baru.

2. Staf Administrasi melakukan pengentrian data siswa ke dalam aplikasi pengolahan data Pendidikan Anak Usia Dini (PAUD) Terpadu Amalia Syukra.

3. Setelah terdaftar sebagai siswa, staf administrasi melakukan pengentrian data kelas siswa ke dalam aplikasi pengolahan data Pendidikan Anak Usia Dini (PAUD) Terpadu Amalia Syukra.

4. Apabila ada siswa yang membayar uang SPP, staf administrasi melakukan pengentrian data pembayaran uang SPP siswa ke dalam apliksi pengolahan data Pendidikan Anak Usia Dini (PAUD) Terpadu Amalia Syukra dan siswa diberi Slip Pembayaran Uang SPP dan siswa di beri slip pembayaran uang SPP.

5. Apabila ada siswa yang akan menabung maka staf administrasi melakukan pengentrian data tabungan siswa kedalam apliksi pengolahan data Pendidikan Anak Usia Dini (PAUD) Terpadu Amalia Syukra, begitu juga sebaliknya apabila ada siswa yang akan mengambil uang tabungannya maka staf administrasi juga melakukan pengentrian data pengambilan uang tabungan dan siswa diberi slip saldo tabungan.

6. Setelah tahun ajaran telah selesai maka Staf Administrasi melakukan pengentrian data kelulusan siswa ke dalam aplikasi pengolahan data Pendidikan Anak Usia Dini (PAUD) Terpadu Amalia Syukra.

7. Guru memberikan data guru kepada Staf Administrasi PAUD Terpadu Amalia Syukra Padang.

8. Staf administrasi melakukan pengentrian data guru kedalam aplikasi pengolahan data Pendidikan Anak Usia Dini (PAUD) Terpadu Amalia Syukra.

9. Apabila sudah akhir bulan maka staf administrasi melakukan pengentrian data gaji guru ke dalam aplikasi pengolahan data Pendidikan Anak Usia Dini (PAUD) Terpadu Amalia Syukra.

10. Staf Administrasi melakukan pengentrian data uang yang keluar setiap terjadi

transaksi ke dalam aplikasi pengolahan data Pendidikan Anak Usia Dini (PAUD) Terpadu Amalia Syukra.

11. Dari database dbpaud, staf administrasi membuat laporan siswa baru, laporan kelas siswa, laporan tabungan siswa, laporan pembayaran uang SPP, laporan kelulusan siswa, laporan biodata guru, laporan gaji guru dan laporan uang keluar (PAUD) Terpadu Amalia Syukra Padang kepada Kepala Sekolah untuk disetujui masisng-masing dua rangkap, satu rangkap untuk Kepala Sekolah dan satu lagi untuk disimpan oleh Staf Administrasi.

12. Dari database dbpaud, Staf Administrasi memberikan slip gaji guru kepada Kepala Sekolah untuk di setujui sebanyak tiga rangkap untuk 
guru, staf administrasi dan kepala sekolah.

Untuk lebih jelasnya kerja system informasi pengolahan data Pendidikan Anak Usia dini (PAUD) terpadu Amalia Syukra Padang yang diusulkan dapat dilihat pada gambar 1 berikut ini :

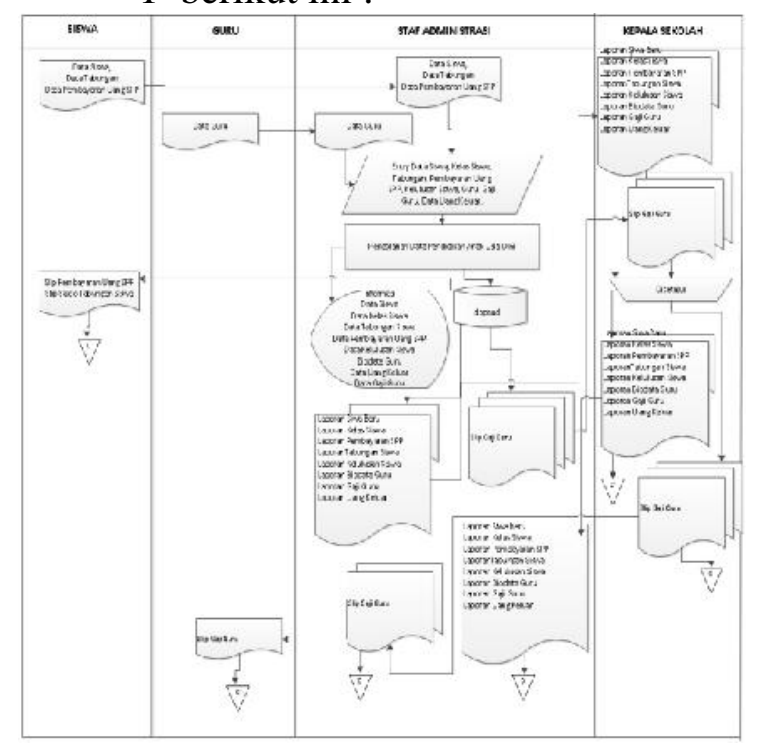

Gambar 1. Aliran Sistem Informasi yang diusulkan

Berdasarkan permasalahan dan kendala-kendala yang terjadi pada sistem yang sedang berjalan pada saat ini maka perlu dibangunnya sebuah software aplikasi Sistem Informasi pengolahan data Pendidikan Anak Usia Dini (PAUD) Terpadu Amalia Syukra Padang. Sistem ini diharapkan dapat berfungsi untuk:

1. Mengolah data Pendidikan Anak Usia Dini pada (PAUD) Terpadu Amalia Syukra Padang dengan cepat, sehingga proses pengolahan dapat terlaksana lebih cepat dan tepat.
2. Melakukan pencarian informasi dan penyajian informasi mengenai data Pendidikan Anak Usia Dini pada (PAUD) Terpadu Amalia Syukra Padang lebih cepat.

3. Pembuatan laporan yang diinginkan dapat dilakukan kapan saja tanpa membutuhkan waktu yang lama karena data Pendidikan Anak Usia Dini telah tersimpan dalam database.

\section{c. Perancangan Sistem}

Perancangan Sistem Informasi Pengolahan Data PAUD ini menggunakan Hierarchy Input Process Output (HIPO). HIPO merupakan gambaran dari modul program yang dirancang pada sistem pengolahan data secara komputerisasi, untuk pengolahan data Pendidikan Anak Usia Dini (PAUD) Terpadu Amalia Syukra Padang dapat dilihat pada Gambar 2 berikut ini:

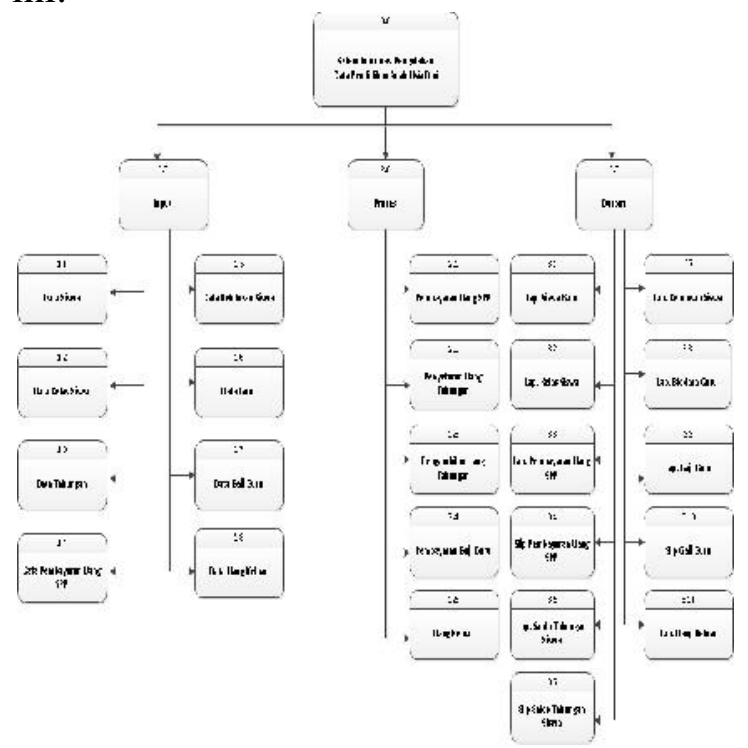

Gambar 2 HIPO Sistem Informasi Pengolahan Data Pendidikan Anak Usia 


\section{Dini (PAUD) Terpadu Amalia Syukra Padang}

Selain dengan HIPO perancangan system juga dapat dibuat dengan Data Flow Diagram (DFD). DFD merupakan gambaran sistem secara logika yang tidak tergantung pada perangkat keras, lunak, struktur data dan organisasi file. Keuntungan dari DFD adalah untuk memudahkan pemakai yang kurang menguasai bidang komputer untuk mengerti sistem yang akan dikerjakan atau dikembangkan.

DFD level 1 (one) Sistem Informasi Pengolahan Data pada Pendidikan Anak Usia Dini Terpadu Amalia Padang dapat dilihat pada Gambar3 berikut ini:

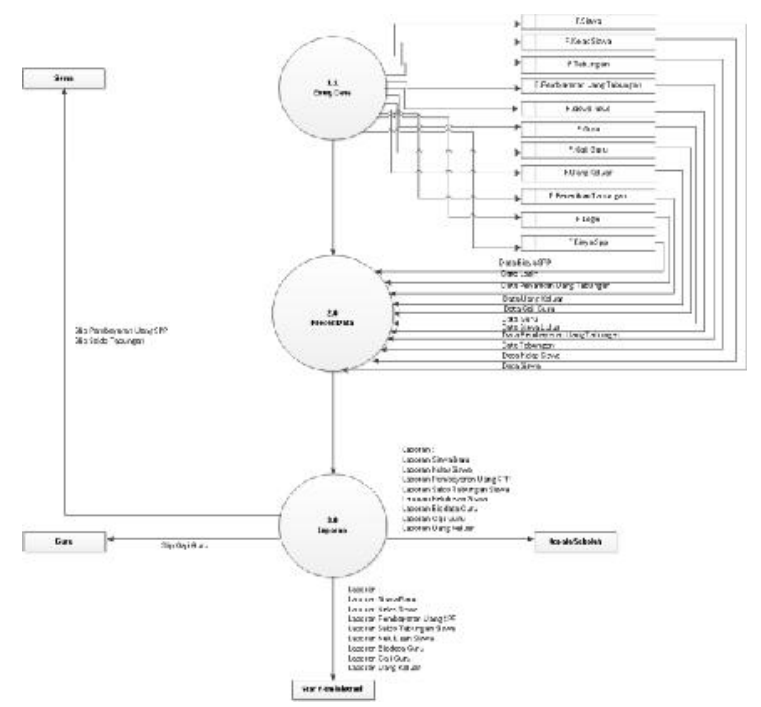

Gambar 3 DFD Sistem Pengolahan Data Pendidikan Anak Usia Dini Pada PAUD) Terpadu Amalia Syukra Padang

\section{d. Pembahasan Hasil Penelitian}

Pada poin ini berisi tentang implementasi sistem serta pembahasannya yaitu sebagai berikut:

\section{1). Input}

Dalam sub menu input terdiri dari beberapa form entri data yang dibutuhkan oleh Staf Administrasi untuk pengolahan data pendidikan anak usia dini. Form input tersebut terdiri dari entry data guru, entry data siswa, entry data kelas siswa, entry data tabungan siswa, entry data pembayaran uang SPP, entry data kelulusan siswa, entry data gaji guru, dan entry data uang keluar lain-lain.
a) Menu Utama

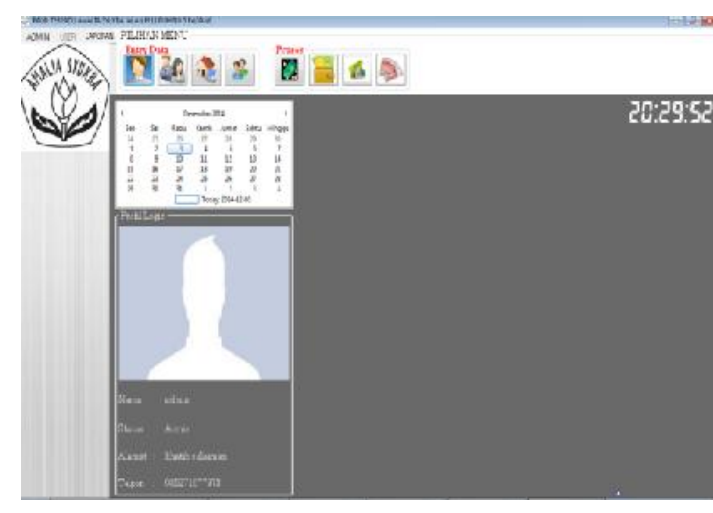

\section{Gambar 5 Menu Utama Sistem Informasi Pengelolaan Data Pada Pendidikan Anak Usia Dini (PAUD) Terpadu Amalia Syukra Padang}

b). Entry Data Siswa 


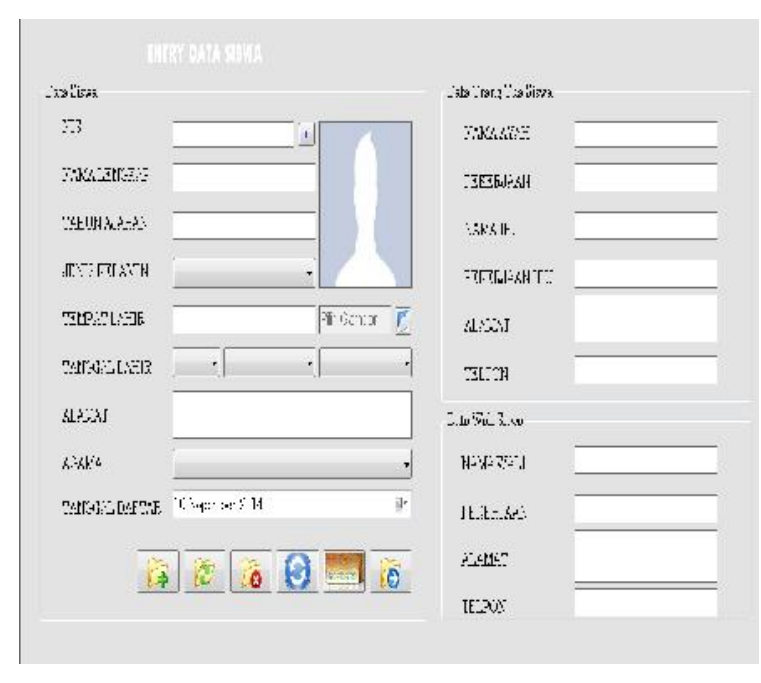

\section{Gambar 6 Form Entri Data Siswa}

\section{c). Entry Data Tabungan Siswa}

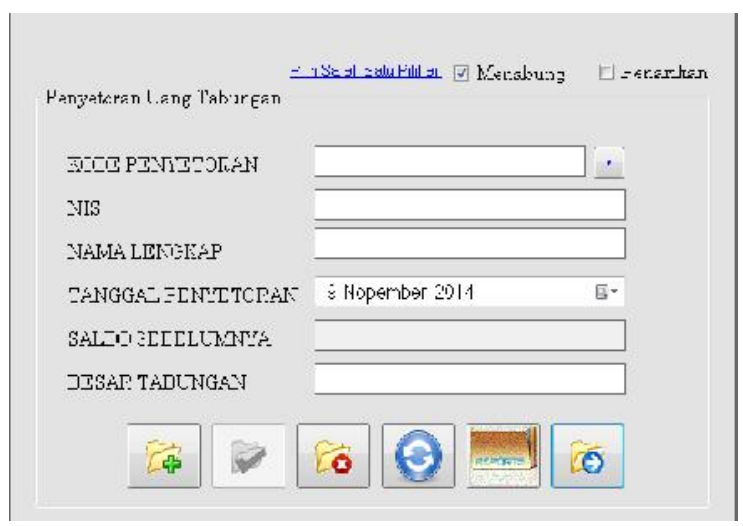

Gambar 7 Entry Data Tabungan Siswa

\section{2). Proses}

Pada form proses pengolahan data terdapat proses pembayaran uang SPP, proses penyetoran uang tabungan, proses penarikan uang tabungan, proses pembayaran gaji guru, proses uang keluar lain-lain, proses pendaftaran login, proses ganti password admin, proses ganti password user, proses perubahan biaya SPP, proses pencarian data guru, proses pencarian data siswa, proses pencarian data kelas, proses pencarian data kelulusan siswa, proses pencarian data pembayaran uang SPP, proses pencarian data penyetoran uang tabungan, proses pencarian data penarikan uang tabungan, proses pencarian data gaji guru dan proes pencarian data uang keluar lain-lain.

\section{3). Output}

Dalam $s u b$ menu laporan terdiri dari beberapa laporan yaitu laporan siswa baru, laporan kelas siswa, laporan pembayaran uang SPP, slip pembayaran uang SPP, laporan saldo tabungan siswa, slip saldo tabungan siswa, laporan kelulusan siswa, laporan biodata guru, laporan gaji guru, laporan uang keluar dan laporan keuangan.

Adapun laporan siswa pada Pendidikan Anak Usia Dini (PAUD) Terpadu Amalia Syukra Padang dapat dilihat pada gambar-gambar berikut ini:

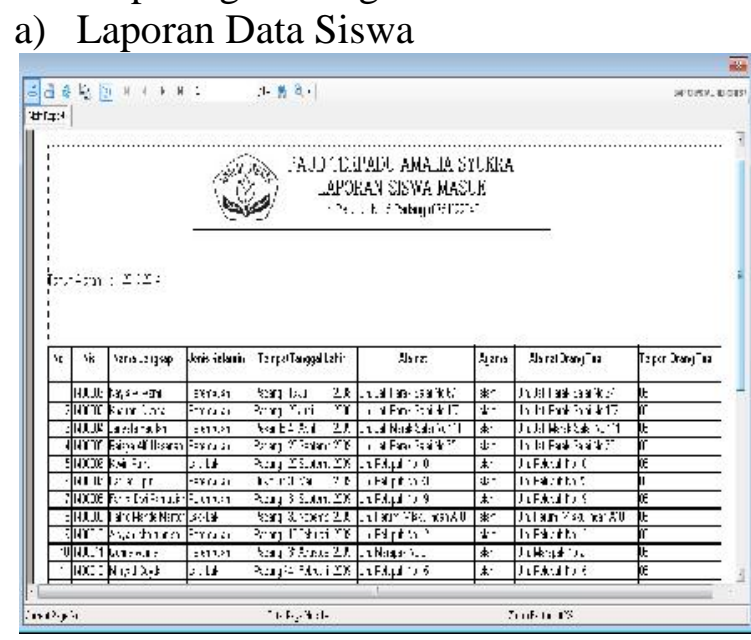

Gambar 8 Laporan Siswa Baru

210 Diterbitkan Oleh Program Studi Pendidikan Informatika STKIP PGRI Sumbar 
b). Laporan Pembayaran Uang SPP siswa

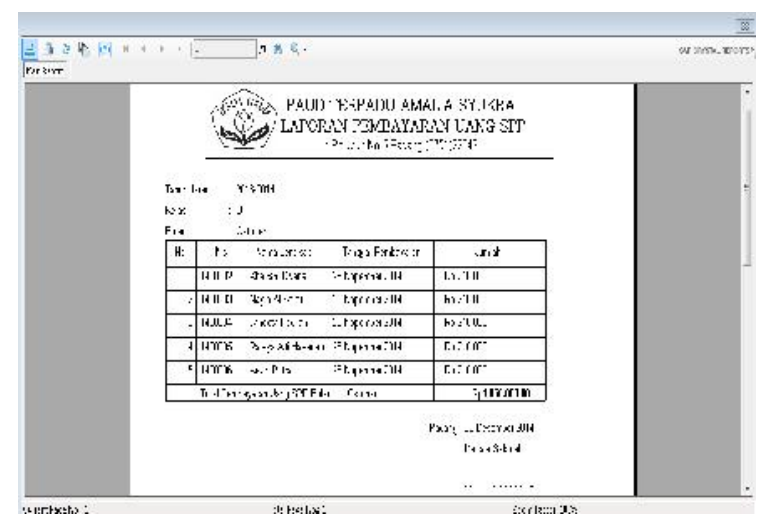

Gambar 9 Laporan Pembayaran Uang SPP Perbulan

b) Laporan Kelulusan Siswa

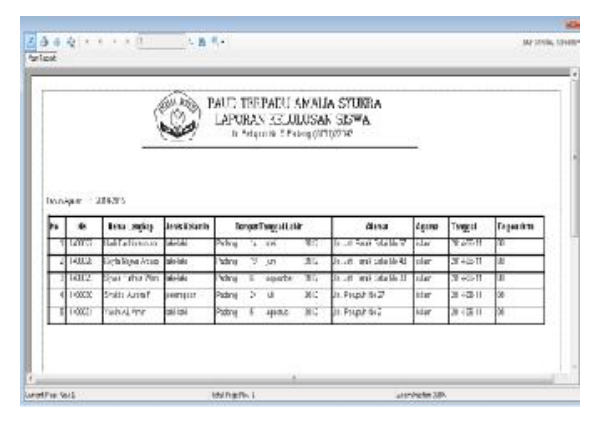

\section{Gambar 10 Laporan Kelulusan Siswa}

\section{KESIMPULAN}

Berdasarkan pembahasan yang telah dilakukan pada bab-bab sebelumnya serta analisa yang telah dilakukan terhadap sistem yang lama, maka penulis dapat mengambil kesimpulan sebagai berikut:

1. Sistem yang sedang berjalan pada saat ini belum mempuyai database sehingga pengolahan data pendidikan masih manual, sedangkan sistem informasi yang diusulkan sudah mengunakan database serta dapat terkoneksi dengan baik dan data tersimpan terpusat dalam database.
2. Setelah dilakukan implementasi aplikasi Sistem Informasi pengolahan data pendidikan anak usia dini pada (PAUD) Terpadu Amalia Syukra Padang, memudahkan staf administrasi dalam mengolah data Pendidikan Anak Usia Dini sehingga mudah mengetahui data siswa, data guru, data kelas siswa, data pembayaran uang SPP, data tabungan siswa, data kelulusan siswa, data gaji guru dan data transaksi uang keluar.

3. Aplikasi pengolahan data pendidikan anak usia dini (PAUD) Terpadu Amalia Syukra Padang dapat menjaga keamanan data yang telah disimpan pada database karna setiap membuka aplikasi user atau admin harus menginputkan nama user dan password terlebih dahulu.

\section{DAFTAR PUSTAKA}

Al-Bahra Bin Ladjamudin. (2005). “Analisis Dan Desain Sistem Informasi"._Yogyakarta: GRAHA ILMU

(Terstruktur dan Berorientasi Objek). Bandung: Modula.

Abdul Kadir. (2008) dalam buku "Belajar Database Menggunakan MySQL", Yogyakarta: Andi Offset

Edy Winarno ST, M.Eng, Ali Zaki,SmitDev Community. (2010), “Web Programming dengan Visual Basic 2010", Yogyakarta: Andi

Edhy Sutanta. (2011). "B asis Data", Yogyakarta: Andi Offset

Hanif Al Fatta. (2007). “Analisis \& Perancangan Sistem Informasi", Yogyakarta: Andi Offset 
Jalaludin (2002). "Dahulukan Akhlak di Atas Fikih". Bandung. PT. Remaja Rosdakarya.

Jogiyanto HM. (2005). "Analisa dan

Desain Sistem Informasi.

Yogyakarta: Andi Offset.

Komputer, Wahana.(2010). "Pengolahan

Database dengan M ySQ L",

Yogyakarta: ANDI

Komputer, Wahana. (2013:), "Visual Basic

2012 Source Code “, Yogyakarta: ANDI

Kusrini \& Andri Koniyo. (2007).,

Tuntunan Praktis Membangun

Sistem Informasi Akutansi dengan Visual Basic dan Microsoft

SQL", Yogyakarta: Andi Offset

Rohmat Taufiq. (2013). "Sistem

Informasi Manajemen",

Yogyakarta: GRAHA ILMU

Rachamd Hakim. (2009:). "Microsoft

Visual Basic NET 2008”,

Yogyakarta: ANDI

Thamrin abdullah. (2012). "Manajemen

Pemasaran", Yogyakarta: Andi

Offset

Tata Sutabri. (2012). “Analsisis Sistem

Informasi". Yogyakarta: Andi

Offset 